\title{
Identification of nursery habitats for commercially valuable humphead wrasse Cheilinus undulatus and large groupers (Pisces: Serranidae) in Palau
}

\author{
Mark Tupper ${ }^{1,2, *}$ \\ ${ }^{1}$ The WorldFish Center, PO Box 500 GPO, 10670 Penang, Malaysia \\ ${ }^{2}$ Marine Lab, University of Guam, UOG Station, Mangilao, Guam 96923, USA
}

\begin{abstract}
In recent years there has been increasing interest in conserving fish habitats. However, fish-habitat associations, particularly nursery habitat for early juvenile stages, are poorly known for most reef fishes. Using mark-recapture techniques, I examined among-habitat variation in settlement, post-settlement growth, and persistence, and movement in 3 large, vulnerable, and commercially important reef fishes: the humphead wrasse Cheilinus undulatus, the squaretail coralgrouper Plectropomus areolatus, and the camouflage grouper Epinephelus polyphekadion. Both the humphead wrasse and the coralgrouper appeared to utilize specific nursery habitats. Settlement, growth, and persistence of humphead wrasse were highest in branching coral structures mixed with bushy macroalgae (BCMA). Of all tagged $C$. undulatus recaptured in intermediate or adult habitats, $80 \%$ were tagged post-settlement in BCMA. Early juvenile P. areolatus were found almost exclusively in coral rubble habitats on the slopes of tidal channels, at a narrow depth range of 5 to $7 \mathrm{~m}$. This dependence on one habitat type could render this species vulnerable to shipping or dredging operations or other forms of coastal development. E. polyphekadion appeared to be a habitat generalist, and no specific nursery habitat could be identified. In summary, spatial management (e.g. implementation of marine protected areas) should prioritize habitats for conservation according to their value as essential nursery or spawning habitats for target species needing protection.
\end{abstract}

KEY WORDS: Fish habitat $\cdot$ Nursery areas $\cdot$ Grouper $\cdot$ Humphead wrasse

\section{INTRODUCTION}

The management of a marine fishery is a difficult task and in tropical island nations, where ecologically complex ecosystems are under heavy pressure from rapidly increasing anthropogenic stress, the problem is exacerbated. In recent years, there has been increasing interest in conserving fish habitats (e.g. Benaka 1999, Nagelkerken et al. 2000a,b, 2001, 2002, Mumby et al. 2004). Identification of what habitats are important for marine fishes is difficult, because their habitat requirements are poorly understood (Cook \& Auster 2005). In particular, very little is known about habitat utilization patterns of reef fish in the Pacific Islands.

Among the most commercially valuable and most vulnerable nearshore reef fishes in the US Pacific Islands are the larger species such as large wrasses and groupers. These species are slow growing and long lived, with delayed reproductive development and spawning occurring in aggregations and low replenishment rates (Rhodes \& Sadovy 2002, Sadovy et al. 2003a,b). These life-history traits render them particularly susceptible to overexploitation (Donaldson \& Sadovy 2001). Groupers and humphead wrasse Cheilinus undulatus are major components of the live reef fish trade and are subject to intense fishing pressure. Catches have declined dramatically over the past few decades (Myers 1999). The humphead wrasse has been listed as 'vulnerable' by the World Conservation Union (IUCN Red List of Threatened Species, www.redlist. org) and was listed in Appendix II of the Convention on International Trade in Endangered Species of Fauna and Flora (CITES) in October 2004. In addition to their fishery value, large reef fishes are important to divers 
and have high tourism value (Rudd \& Tupper 2002). Determining nursery habitat for large groupers and humphead wrasse may be problematic in that many large reef fishes undergo stage-dependent, ontogenetic habitat shifts. For example, juvenile serranids and lutjanids are known to settle on small patch reefs, in seagrasses, among mangrove prop roots, or in algaldominated clumps of coral in the western Atlantic (Eggleston 1995, Sullivan \& Sluka 1996, Koenig \& Coleman 1998). As juvenile fish grow, their risk of predation likely decreases, while their foraging capacity and probability of survival likely increase (Tupper \& Boutilier 1997). Larger size also initiates higher metabolic demands, and juveniles may need to find a more suitable habitat to meet these requirements.

In order to better manage these species, especially in terms of spatial management via marine protected areas, we require detailed information on their habitat utilization patterns. Simply identifying the habitats that fish use is inadequate, as such a broad approach to determining essential habitat does not allow for prioritization of habitats for conservation and management (Levin \& Stunz 2005). A better approach would be to concentrate conservation and restoration efforts on habitats or sites that are most important for the replenishment of adult populations. The most obvious examples in Palau are spawning aggregation sites and nursery habitats. Palau has already implemented year-round fishing closures at 2 well-known grouper spawning aggregation sites (Ngerumekaol Conservation Area and Ebiil Conservation Area), but to date there are no policies in place to identify or protect nursery habitats.

Beck et al. (2001) outline a more rigorous approach to determining nursery habitat. They suggest that a true nursery is a juvenile habitat that provides disproportionately greater biomass per unit area to adult populations. In order to determine if a particular habitat or habitats is truly a nursery, a suite of important ecological processes must be measured within all available habitat types. These include density, growth, survival, and movement to adult (or intermediate) habitats (Beck et al. 2001). All of these processes may contribute to a higher production of biomass recruiting to the adult population.

The objective of the present study was to determine nursery habitat (as defined by Beck et al. 2001) for 3 species of commercially valuable reef fishes in Palau: humphead wrasse Cheilinus undulatus, squaretail coralgrouper Plectropomus areolatus, and camouflage grouper Epinephelus polyphekadion. Specifically, mark-recapture techniques were used to compare density, persistence, growth, and movement of newly settled groupers and humphead wrasse in a variety of habitat types.

\section{MATERIALS AND METHODS}

Study sites. The study was conducted at selected sites in the main Palau archipelago (Fig. 1). Five sites were chosen within the lagoon: 2 in the western lagoon, 2 in the eastern lagoon, and 1 in the Rock Islands. Four sites were chosen along the western (leeward) barrier reef. Sites were chosen in order to represent a wide array of available habitat types. Sites were not chosen on the eastern (windward) barrier reef, due to persistent rough seas that limited regular access to that area. Shallow nearshore habitats were broadly classified as mangroves, seagrasses, patch reefs, fringing reefs, offshore bank or barrier reefs, sand/algal plains, and tidal channels. Offshore reef habitats were further subdivided into zones (reef flat, reef crest, submarine terrace, reef slope, etc.).

Intensive surveys of each of the 9 study sites were undertaken from July 2002 to February 2003. At each site, divers conducted 3 timed swims, each of $20 \mathrm{~min}$ duration, in haphazard directions. During these swims, divers searched for juvenile $(<150 \mathrm{~mm}$ TL) Chilinus undulatus, Plectropomus areolatus and Epinephelus polyphekadion. Divers recorded the presence of any juveniles and the microhabitat in which they were found.

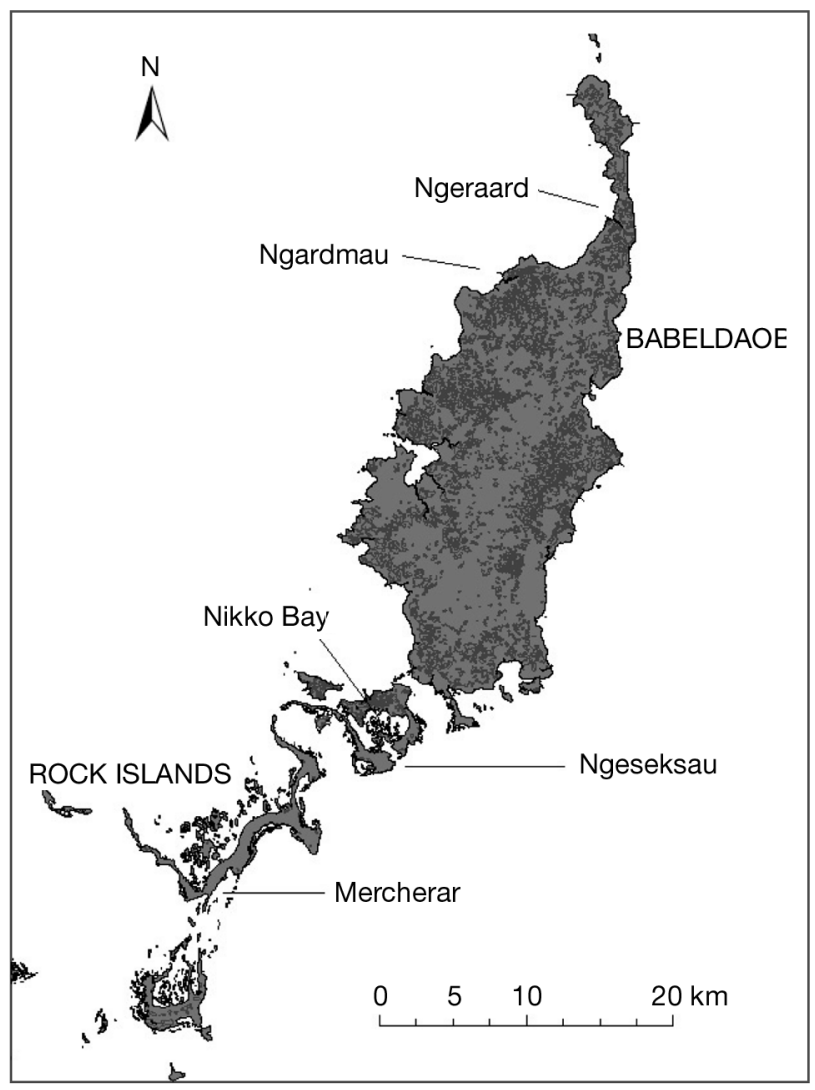

Fig. 1. Map of Palau showing location of lagoon study sites, where experiments were conducted 
Coral heads, rubble areas, algal clumps, and any other microhabitats in which early juveniles could be hiding were squirted a very light dose of $10 \%$ solution of quinaldine sulfate. At higher doses, this anesthetic can be used to immobilize and capture fish (e.g. for markrecapture experiments, see below). Our aim in this case was to simply flush the cryptic juveniles out of their hiding places, as visual census alone would have missed any cryptic juveniles and biased our identification of potential nursery habitats.

Our initial surveys of the 9 sites indicated that juvenile Cheilinus undulatus were abundant enough to conduct mark-recapture experiments at 4 lagoon sites, 2 on the western side of Palau (Ngeraard, Ngardmau) and 2 on the eastern side (Mercherar, Nikko Bay; Fig. 1). Juvenile groupers were sufficiently abundant at 5 sites: the above-mentioned four plus Ngeseksau. No recently settled juveniles were found on any of the offshore barrier reef sites. At each of 5 lagoon sites, a total of 11 microhabitat types were identified as potential nursery habitats for juvenile $C$. undulates, Plectropomus areolatus, and Epinephelus polyphekadion, based on the presence of juveniles in these microhabitats. These microhabitats included sand, coral rubble, limestone pavement (consolidated low-relief limestone bottom with $<20 \%$ colonization), mangrove prop roots, seagrass beds ( $>50 \%$ coverage of seagrass), filamentous macroalgae ( $>50 \%$ coverage of filamentous algal turf), fleshy macroalgae ( $>50 \%$ coverage of lobular forms such as Padina spp.), bushy macroalgae (>50\% coverage of branching macroalgae, commonly Laurencia spp. or similar species), massive corals (most commonly massive forms of Porites rus), branching corals (e.g. Acropora spp., Seriotopora spp., and Porites cylindricus), and low branching corals combined with bushy macroalgae. This last microhabitat type was particularly common in shallow (1 to $2 \mathrm{~m}$ mean low tide) bank areas (Ngeraard and Ngardmau). All microhabitat types were present at all sites, except mangroves, which did not occur at Mercherar.

Fish habitat utilization. Among-habitat variation in settlement: Settlement surveys took place from March 2003 through February 2004. Cheilinus undulatus in Palau appears to settle in a bimodal temporal pattern, with seasonal peaks in May and October (M. Tupper unpubl. data). Plectropomus areolatus in Palau appear to spawn from January to October, or possibly year-round (Johannes 1981, Johannes et al. 1999), and the youngof-the-year settle from May to November with a peak in August (M. Tupper unpubl. data). Epinephelus polyphekadion have a shorter spawning season, mainly June and July (Johannes 1981, Johannes et al. 1999), and recently settled fish are most abundant in August (M. Tupper unpubl. data). Mark-recapture studies of recent settlers were initiated during seasonal density peaks, i.e. May and October for $C$. undulatus and August for the 2 grouper species. Thus, information on postsettlement processes (growth, persistence, and movement) could be gathered for at least 6 mo after tagging.

At each site and within each microhabitat, newly settled Cheilinus undulatus (i.e. all individuals $\leq 15 \mathrm{~mm}$ total length [TL] and newly arrived since the previous census) and groupers ( $\leq 25 \mathrm{~mm} \mathrm{TL}$ ) were visually censused monthly by SCUBA diving or snorkeling along 5 haphazardly placed $25 \mathrm{~m} \times 2 \mathrm{~m}$ belt transects. Each site could only be censused monthly because of the large number of transects involved in this study. Since each of the 5 sites had 11 microhabitats to be surveyed (except Mercherar which had no mangroves), there were 54 site-habitat combinations, each censused with 5 replicate transects, for a total of 270 transects. Each microhabitat covered sufficient area to allow the use of a $25 \mathrm{~m}$ transect, with the exception of filamentous macroalgae. Transects in this microhabitat were broken into $5 \mathrm{~m}$ sections to fit the areas of filamentous macroalgae.

Due to the large number of zero values involved in settlement surveys, all data were tested for normality using the Kolmogorov-Smirnov D-test and for homogeneity of variance using Levene's test and were $\log (x+1)$ transformed when assumptions of parametric analysis were not met. Transformed data met assumptions of normality and homogeneity of variance. Analysis of variance (ANOVA) was used to test the null hypothesis that settlement does not differ among habitat types.

Among-habitat variation in abundance, growth, persistence, and movement: Cheilinus undulatus settled at a size of 8 to $15 \mathrm{~mm} \mathrm{TL}$, with a mode of about $12 \mathrm{~mm}$ TL (M. Tupper unpubl. data). This small size makes newly settled individuals inappropriate for mark-recapture studies, as the mortality associated with the marking process is likely to be unacceptably high (e.g. $28 \%$ in haemulids of 11 to $15 \mathrm{~mm} \mathrm{TL}$; Tupper \& Juanes 1999). Mortality associated with this technique is typically 8 to $10 \%$ for fishes of 20 to $30 \mathrm{~mm}$ TL (Tupper \& Boutilier 1995, 1997, Tupper \& Juanes 1999). Pilot marking trials indicated that individuals of $35 \mathrm{~mm}$ TL and larger could be marked with $<10 \%$ mortality ( 2 deaths in 22 trials). Thus, only individuals of $>35 \mathrm{~mm}$ TL (about 2 to 3 wk post-settlement) were marked. In each microhabitat type, early juveniles of 35 to $50 \mathrm{~mm}$ TL were captured using a $10 \%$ solution of the anesthetic quinaldine sulfate. Groupers settle at a size of roughly $25 \mathrm{~mm}$, and can be marked successfully within a few days to a week after settlement. All captured fish were measured to the nearest millimeter TL and marked in situ with subcutaneous injections of visible implant elastomer (Northwest Technologies, Inc.), using a different pattern of colored dots for each site and habitat. Marked fish were released immediately at their point of capture. A detailed habitat description 
(species of coral/algae and approximate percentage cover) was made at each capture point, and the location was recorded using a hand-held GPS unit.

The mark-recapture study began in February 2004, following the settlement surveys. Following initial tagging of the fish, growth and persistence (i.e. the reciprocal of mortality and/or emigration) of juveniles was estimated by 12 successive censuses and recaptures of marked individuals, performed every $2 \mathrm{wk}$ for 6 mo along the same transects. Surveys of postsettlement fish could be conducted every 2 wk, because the fish settled into only 6 of the 11 available habitat types (see 'Results'), greatly reducing the number of transects that needed to be surveyed. A total of 250 recently settled Cheilinus undulatus were tagged with elastomer injections (100 at Ngeraard and 50 each at Ngardmau, Nikko Bay, and Mercherar). Tags were divided among microhabitat types as follows: 80 in low branching coral with associated macroalgae, 50 in branching coral, 50 in bushy macroalgae, 35 in seagrass, and 35 in coral rubble. A balanced, orthogonal design was not possible because of the lower numbers of fish settling into seagrass and rubble microhabitats. Table 1 shows the distribution of tags among sites and microhabitats for all 3 study species. A total of 73 newly settled Plectropomus areolatus were tagged (all in coral rubble): 25 at Ngeseksau and 12 each at Mercherar, Ngeraard, Ngardmau, and Nikko Bay. Due to the difficulty in catching the highly cryptic Epinephelus polyphekadion, and the variation in settlement to different habitats, a balanced number of tags per microhabitat was not possible.

At each successive census, all recaptured individuals were measured to the nearest millimeter TL, and their locations were recorded by GPS, as above. Cumulative percent persistence of released fish was estimated as the number in census/total number released $\times 100 \%$. Note that persistence is an underestimate of true survival as the methodology cannot completely account for emigration of tagged fishes that were not recaptured in censuses of surrounding areas. To determine movement patterns of post-settlement juveniles, points were haphazardly selected at distances of $3,10,50$, and $100 \mathrm{~m}$ from each original tag/release site. These

Table 1. Number of recently settled juveniles tagged in each microhabitat type at 5 sites in Palau, Micronesia

\begin{tabular}{|c|c|c|c|c|}
\hline Site & Microhabitat & $\begin{array}{l}\text { Cheilinus } \\
\text { undulatus }\end{array}$ & $\begin{array}{l}\text { Plectropomus } \\
\text { areolatus }\end{array}$ & $\begin{array}{c}\text { Epinephelus } \\
\text { polyphekadion }\end{array}$ \\
\hline \multirow[t]{6}{*}{ Ngardmau } & Low branching coral with associated macroalgae & 20 & 0 & 3 \\
\hline & Branching coral & 12 & 0 & 4 \\
\hline & Bushy macroalgae & 12 & 0 & 0 \\
\hline & Seagrass & 8 & 0 & 0 \\
\hline & Massive corals & 0 & 0 & 4 \\
\hline & Coral rubble & 8 & 12 & 3 \\
\hline \multirow[t]{6}{*}{ Ngeraard } & Low branching coral with associated macroalgae & 20 & 0 & 0 \\
\hline & Branching coral & 14 & 0 & 3 \\
\hline & Bushy macroalgae & 14 & 0 & 0 \\
\hline & Seagrass & 11 & 0 & 0 \\
\hline & Massive corals & 0 & 0 & 4 \\
\hline & Coral rubble & 11 & 25 & 4 \\
\hline \multirow[t]{6}{*}{ Ngeseksau } & Low branching coral with associated macroalgae & 0 & 0 & 3 \\
\hline & Branching coral & 0 & 0 & 2 \\
\hline & Bushy macroalgae & 0 & 0 & 0 \\
\hline & Seagrass & 0 & 0 & 0 \\
\hline & Massive corals & 0 & 0 & 4 \\
\hline & Coral rubble & 0 & 12 & 4 \\
\hline \multirow[t]{6}{*}{ Nikko Bay } & Low branching coral with associated macroalgae & 20 & 0 & 0 \\
\hline & Branching coral & 12 & 0 & 0 \\
\hline & Bushy macroalgae & 12 & 0 & 0 \\
\hline & Seagrass & 8 & 0 & 0 \\
\hline & Massive corals & 0 & 0 & 0 \\
\hline & Coral rubble & 8 & 12 & 3 \\
\hline \multirow[t]{6}{*}{ Mercherar } & Low branching coral with associated macroalgae & 20 & 0 & 3 \\
\hline & Branching coral & 12 & 0 & 2 \\
\hline & Bushy macroalgae & 12 & 0 & 0 \\
\hline & Seagrass & 8 & 0 & 0 \\
\hline & Massive corals & 0 & 0 & 4 \\
\hline & Coral rubble & 8 & 12 & 4 \\
\hline
\end{tabular}


points were used as the starting points for further $25 \mathrm{~m}$ transects, to search for tagged fish that may have emigrated from their original tag and release point. The null hypotheses that neither growth nor persistence vary among microhabitats was tested using ANOVA. Persistence data is proportional and was therefore arcsine transformed prior to analysis.

\section{RESULTS}

\section{Among-habitat variation in settlement, post-settlement persistence, and growth}

Settlement

Recently settled Cheilinus undulatus (<25 mm TL) were found in 5 of 11 habitats (Fig. 2). The amonghabitat and among-site differences in post-settlement density were statistically significant (2-way ANOVA: $F=43.2, \mathrm{p}<0.0001$ for habitats $F=10.8, \mathrm{p}<0.0001$ for sites). There was a significant interaction term as postsettlement density was highest in low branching coral with associated bushy macroalgae (hereafter BCMA) $(F=5.35, \mathrm{p}<0.0001)$ at all sites except Ngeseksau, where it did not differ from density in branching coral microhabitats. Post hoc comparison tests (Tukey's honestly significant difference, HSD) indicated that habitats fell into 4 groups with respect to postsettlement density: 6 habitats had zero settlement; seagrass and rubble had low settlement and did not differ from each other; branching coral and bushy macroalgae had significantly higher density than the previous groups $(\mathrm{p}<0.05)$, but did not differ from each other, and BCMA had significantly higher settlement $(p<0.0001)$ than all other microhabitats.

Plectropomus areolatus settled almost exclusively in coral rubble along the sides of tidal channels, at a depth of 5 to $7 \mathrm{~m}$. Only $2 P$. areolatus were found on patch reefs, and none were found in any of the other 9 microhabitat types (Fig. 2). Apparently, these grouper species are much more habitat-specific at the
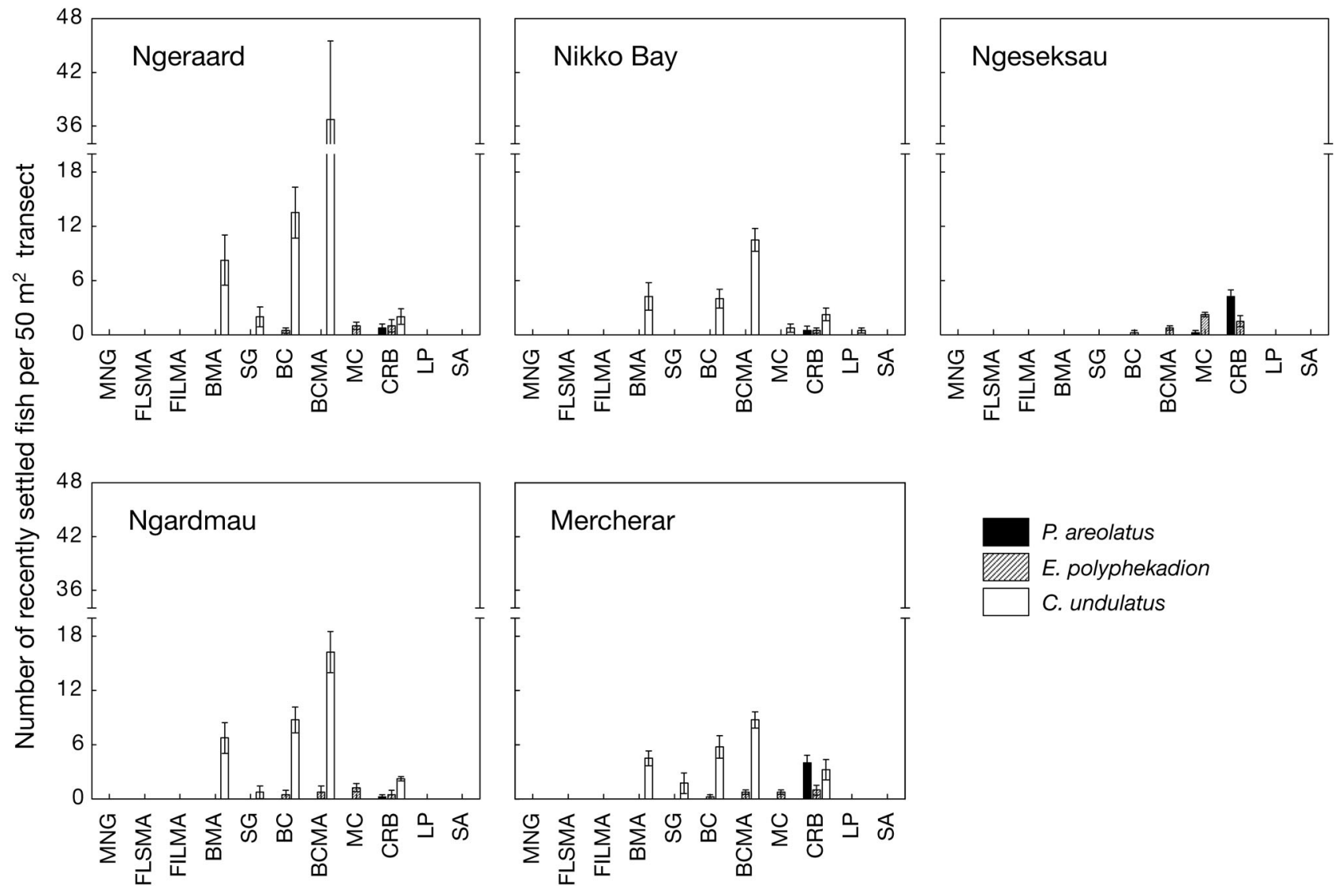

Fig. 2. Among-habitat variation (mean $\pm 1 \mathrm{SE}$ ) in occurrence of recently settled juvenile Cheilinus undulatus, Plectropomus areolatus, and Epinephelus polyphekadion at 5 sites in Palau, Micronesia (BC: branching coral; BCMA: low branching coral with associated macroalgae; BMA: bushy macroalgae; CRB: coral rubble; FILMA: filamentous macroalgae; FLSMA: fleshy macroalgae; LP: limestone pavement; MC: massive corals; MNG: mangroves; SA: sand; SG: seagrass) 
early juvenile stage than Cheilinus undulatus. Within coral rubble microhabitats, settlement differed among sites (ANOVA: $F=47.3, \mathrm{p}<0.0001$ ). Post-settlement density was much higher at sites on the east coast of Palau (Ngeseksau, Mercherar) than at sites on the west coast (Ngeraard, Ngardmau).

Post-settlement density of Epinephelus polyphekadion differed significantly among microhabitats, but not among sites (2-way ANOVA: $F=11.2, \mathrm{p}<0.0001$ for microhabitats; $F=1.34, \mathrm{p}=0.26$ for sites). There was no significant interaction between sites and microhabitats $(F=0.77, \mathrm{p}=0.79)$. There was no clear pattern of density among microhabitats, except that juveniles settled to coral rubble microhabitats at all 5 sites and to coral heads at 4 of 5 sites (Fig. 2). A total of 54 E. polyphekadion were tagged: 6 at Nikko Bay and 12 each at the remaining 4 sites (Table 3 ).

\section{Post-settlement persistence}

Of the 250 tagged Cheilinus undulatus, 112 individuals were resighted. All resighted individuals were recaptured. Two-way ANOVA indicated that post-settlement persistence (Fig. 3) was also significantly different among microhabitats $(F=76.5, \mathrm{p}<$ $0.0001)$, but did not differ between sites $(F=0.18$, $\mathrm{p}=0.91)$. As with settlement, there was no significant interaction term $(F=0.64, \mathrm{p}=0.92)$, as persistence was highest in BCMA at all sites. However, persistence did not differ among the remaining 5 microhabitats in which settlement occurred (Tukey's HSD: $p>0.05$ for all pairwise comparisons). The pattern of settlement and post-settlement persistence indicates that shallow inshore areas with abundant BCMA are likely to be essential nursery areas for $C$. undulatus. Interestingly, this type of nursery habitat is nearly identical to that utilized by the Nassau grouper Epinephelus striatus in the tropical western Atlantic Ocean (Eggleston 1995).

Post-settlement persistence of Plectropomus areolatus could only be measured in coral rubble microhabitats, since early juveniles of this species only occurred to any extent in rubble. Persistence in rubble microhabitats (Fig. 3) differed significantly among sites (ANOVA: $F=43.5, \mathrm{p}<0.0001$ ). As with settlement,
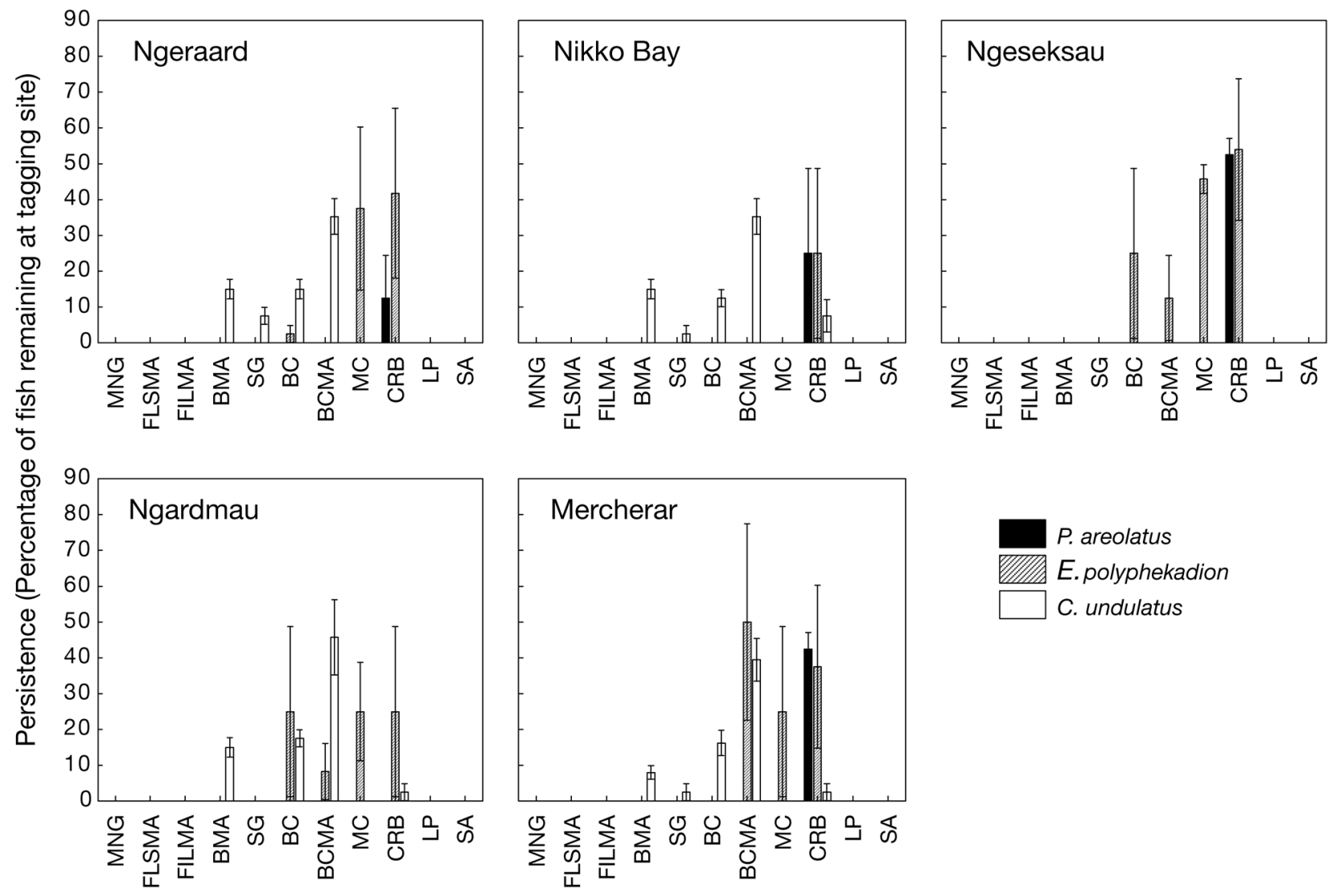

Fig. 3. Among-habitat variation (mean $\pm 1 \mathrm{SE}$ ) in post-settlement persistence of tagged juvenile Cheilinus undulatus, Plectropomus areolatus, and Epinephelus polyphekadion at 5 sites in Palau, Micronesia (abbreviations see Fig. 2) 
persistence was higher at the eastern sites than the at the western or Rock Island sites.

Post-settlement persistence of Epinephelus polyphekadion also differed significantly among microhabitats, but not among sites (2-way ANOVA: $F=$ $6.08, \mathrm{p}<0.0001$ for habitats; $F=0.64, \mathrm{p}=0.59$ for sites). There was no significant interaction term $(F=$ $0.70, \mathrm{p}=0.88$ ). There was no clear pattern in persistence among microhabitats, but persistence tended to be highest in massive corals, coral rubble, and branching coral. Post hoc analyses showed no difference in persistence among these 3 habitats (Tukey's HSD: $\mathrm{p}>0.05$ for all pairwise comparisons). E. polyphekadion persisted for 3 to $4 \mathrm{wk}$ on deeper $(>10 \mathrm{~m})$ rubble areas and coral heads $(>10 \mathrm{~m})$, especially in relatively turbid areas such as channel bottoms at Ngeraard, Mercherar, and Ngeseksau (Fig. 3). E. polyphekadion appeared to become more cryptic in the weeks following settlement. The newly settled fish could often be seen with their heads emerging from their shelter sites, whereas fish $>40$ to $50 \mathrm{~mm}$ were generally found hiding under rocks or large pieces of dead coral.
Growth

Two-way ANOVA indicated that growth of recently settled Cheilinus undulatus (Fig. 4) differed significantly among microhabitats $(F=18.1, \mathrm{p}<0.0001)$, but not among sites $(F=0.94, \mathrm{p}=0.42)$. There was no significant interaction term between microhabitats and sites $(F=$ $0.69, \mathrm{p}=0.88)$. Growth was again higher in combined branching coral and bushy macroalgae than in all other microhabitats, but the difference was not significant (Tukey's HSD: $p=0.23$ ). This was partly a result of highly variable growth in coral rubble microhabitats. Comparing branching coral and bushy macroalgae as separate microhabitats, growth was consistently higher in the macroalgal habitat (Tukey's HSD: p < 0.05). Growth of Plectropomus areolatus in rubble microhabitats (Fig. 4) followed the pattern of settlement and persistence among sites: significantly higher at the eastern sites than elsewhere (ANOVA: $F=41.5, \mathrm{p}<0.0001$ ). Growth of $E$. polyphekadion varied significantly between habitats, but not sites (2-way ANOVA: $F=7.82$, p $<0.0001$ for habitats; $F=0.70, \mathrm{p}=0.55$ for sites). Growth was higher in coral rubble than in other microhabitats (Fig. 4).

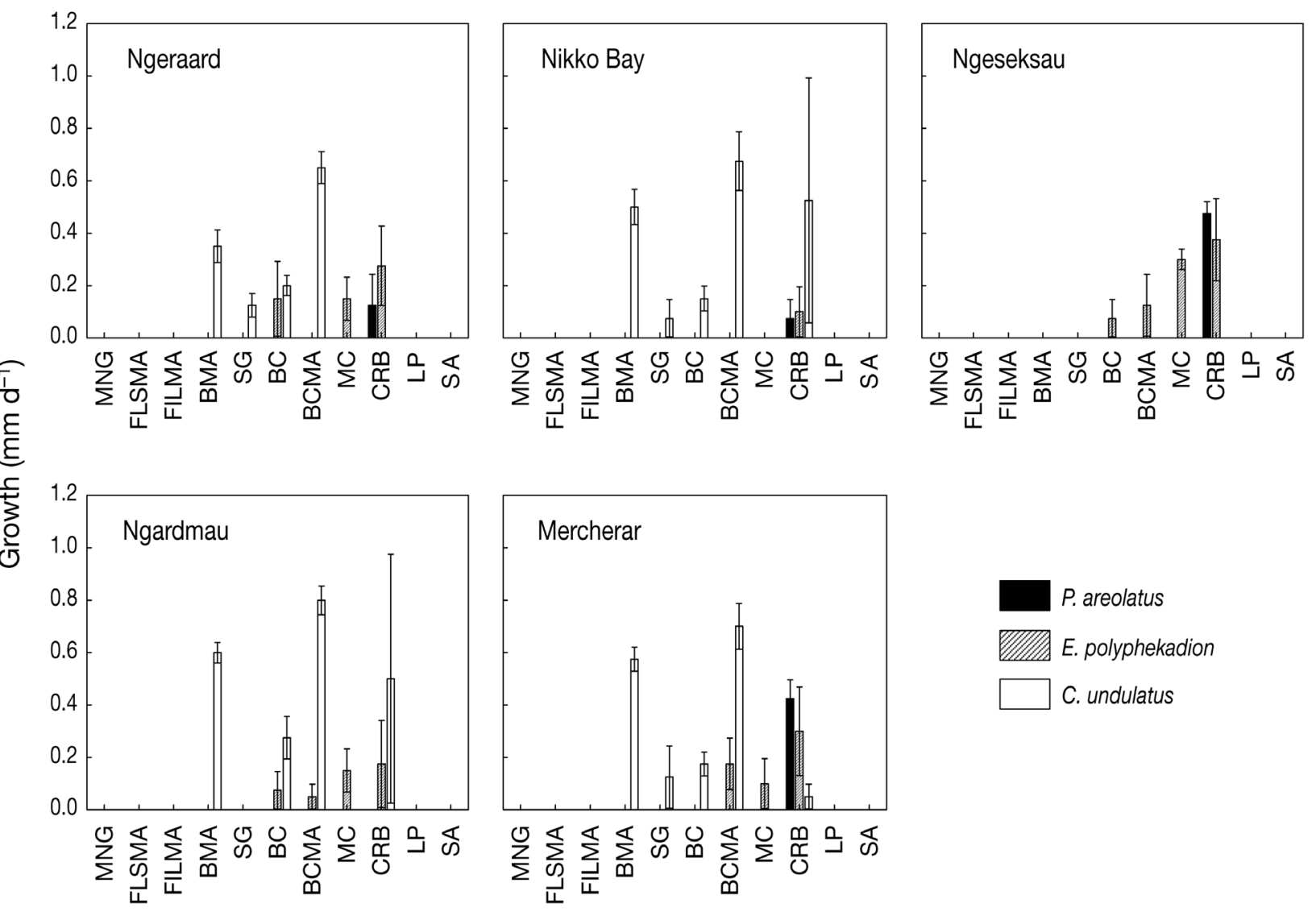

Fig. 4. Among-habitat variation (mean $\pm 1 \mathrm{SE}$ ) in growth of tagged juvenile Cheilinus undulatus, Plectropomus areolatus, and Epinephelus polyphekadion at 5 sites in Palau, Micronesia (abbreviations see Fig. 2) 


\section{Movement of post-settlement fish}

We recorded no movement of tagged Cheilinus undulatus settlers from their initial tagging sites, for approximately 3 mo following settlement. All recaptured individuals $<65 \mathrm{~mm}$ were found within $5 \mathrm{~m}$ of their initial tagging site. After 3 to 6 mo following settlement, 12 fish of 65 to $85 \mathrm{~mm}$ TL were recaptured on patch reefs consisting mainly of massive Porites sp. and Montipora sp. coral heads in deeper (5 to $6 \mathrm{~m}$ ) lagoon areas of Ngeraard, seaward of the settlement habitats (Table 2). At Ngeraard, the average distance moved by juvenile C. undulatus in the 3 to 6 mo following settlement was approximately $90 \mathrm{~m}$ (Table 2). Likewise, 5 older juveniles were recaptured on similar patch reefs at 5 to $6 \mathrm{~m}$ depth, approximately $106 \mathrm{~m}$ seaward of the settlement habitats in Ngardmau. Older juvenile and small adult $C$. undulatus, up to about $250 \mathrm{~mm}$ TL (female C. undulatus are sexually mature at about $20 \mathrm{~cm} \mathrm{TL}$, P. L. Colin unpubl. data), were common in patch reef habitats at Ngeraard and Ngardmau. They were generally observed in close association with coral heads, but were feeding on mollusks and polychaete worms in sand areas adjacent to the coral. In contrast, recently settled $C$. undulatus appeared to feed mainly on small crustaceans within the habitat they settled into (author's pers. obs.). Only 3 older juveniles (65 to $85 \mathrm{~mm}$ ) were recaptured at Nikko Bay, all on coral heads in shallow water $(<2 \mathrm{~m})$, an average distance of $54 \mathrm{~m}$ from their initial tagging site (Table 2), and none were recaptured at Mercherar, which is primarily a rubble and sand channel with shallow (1 to $2 \mathrm{~m}$ ) seagrass beds and small coral heads. Of the 20 fish recaptured in deeper patch reef habitats, 16 (80\%) initially settled in BCMA microhabitat and the remaining $4(20 \%)$ settled in bushy macroalgae microhabitat.

Juvenile Plectropomus areolatus persisted in rubble microhabitats for about 1 mo before leaving for deeper lagoon waters. During this first month, no movement from initial tagging sites was recorded. At $6 \mathrm{wk}$ after initial tagging, 6 fish were recaptured at Ngeseksau and 3 at Mercherar, all on small patch reefs in relatively deep water $(10$ to $20 \mathrm{~m}$ ) and generally $>300 \mathrm{~m}$ from their tagging site (Table 2). This suggests that this species moves offshore to deeper water soon after settlement. None were recaptured at any of the western or central sites (Ngeraard, Ngardmau, and Nikko Bay). Movement patterns of Epinephelus polyphekadion could not be determined from our mark-recapture experiment. Once the tagged fish left the initial settlement site, none were recovered.

\section{DISCUSSION}

Following Beck et al.'s (2001) definition of a nursery habitat as a habitat that supplies disproportionately more biomass to the adult population, 2 of the 3 species in this study actually appear to use an identifiable nursery habitat. Cheilinus undulatus had significantly higher density, growth, and persistence in shallow BCMA, and, while only $32 \%$ of newly settled juveniles were originally tagged in BCMA, $80 \%$ of tagged older (3 to 6 mo postsettlement) juveniles recaptured on deeper lagoon patch reefs originally settled in shallow BCMA habitat. This pattern of settling to a cryptic existence within shallow areas of high-complexity corals overgrown with bushy algae has been reported for other reef fishes, e.g. the Nassau grouper Epinephelus striatus (Eggleston 1995) and 3 species of pygmy angelfishes Centropyge spp. (Eagle et al. 2001). In Tanzania, Dorenbosch et al. (2006) did not find $C$. undulatus inhabiting mangroves or macro-algal flats, but did find smaller individuals $(<27.5 \mathrm{~cm}$ TL) to be most abundant in seagrass beds. They concluded that seagrass beds may play an important role as nurseries for C. undulatus in Tanzania. However, Dorenbosch et al. (2006) used only visual transects to census juveniles, and, without the use of anesthetic, they may have missed many of the cryptic early juveniles in other habitats.

Table 2. Recaptures of older juvenile fish $>3$ mo post-tagging. Origin refers to the habitat into which the fish originally settled and was tagged. Mean distance moved refers to the shortest linear distance between tagging and recapture points, averaged among all recaptured fish at each site (BCMA: low branching corals with associated macroalgae; BM: bushy macroalgae; CR: coral rubble)

\begin{tabular}{|c|c|c|c|c|c|c|}
\hline Species & Site & Habitat & $\begin{array}{l}\text { Depth } \\
\text { (m) }\end{array}$ & Number & Origin & $\begin{array}{c}\text { Mean distance } \\
\text { moved }(\mathrm{m})\end{array}$ \\
\hline \multirow[t]{5}{*}{ Cheilinus undulatus } & Ngeraard & Patch reefs (large massive corals) & $5-6$ & 9 & BCMA & 86 \\
\hline & Ngeraard & Patch reefs (large massive corals) & $5-6$ & 3 & $\mathrm{BM}$ & 97 \\
\hline & Ngardmau & Patch reefs (large massive corals) & $5-6$ & 4 & BCMA & 104 \\
\hline & Ngardmau & Patch reefs (large massive corals) & $5-6$ & 1 & $\mathrm{BM}$ & 112 \\
\hline & Nikko Bay & Patch reefs (small massive corals) & $1-2$ & 3 & BCMA & 54 \\
\hline \multirow[t]{2}{*}{ Plectropomus areolatus } & Ngeseksau & Coral heads on channel bottom & $10-15$ & 6 & $\mathrm{CR}$ & 302 \\
\hline & Mercherar & Coral heads on channel bottom & $15-20$ & 3 & $\mathrm{CR}$ & 351 \\
\hline
\end{tabular}


Coral rubble was obviously essential to Plectropomus areolatus, as it was more or less nonexistent in any other microhabitat at sizes of $<50 \mathrm{~mm}$ TL. A similar pattern of preference for rubble area on the sides of channels, along a fairly narrow depth band, was found for the congener leopard coralgrouper Plectropomus leopardus on the Great Barrier Reef, Australia (Light \& Jones 1997). Epinephelus polyphekadion, however, appeared much less specific in its pattern of habitat use, and there did not appear to be one particular habitat type that was used as a nursery. Since we could not measure post-settlement movement of older juvenile (3 to 6 mo post-settlement), we still know nothing of the migratory pathways of this species from juvenile to adult habitat.

Newly settled Cheilinus undulatus displayed strong site fidelity while in smaller size classes, and tended to remain at or very near their settlement sites for at least 3 mo post-settlement. Indeed, even after 3 to 6 mo post-settlement, a high number recaptures occurred $<100 \mathrm{~m}$ from the initial tagging site. This has been demonstrated for other young-of-year labrids and haemulids in tropical and temperate waters (Tupper \& Boutilier 1995, 1997, Tupper \& Juanes 1999). In contrast, groupers tended to leave their settlement sites within 3 to $4 \mathrm{wk}$ and move to deeper habitats. The few Plectropomus areolatus that were recaptured after 3 to 6 mo had moved $>300 \mathrm{~m}$, 3 times farther than $C$. undulatus. One might expect the groupers to leave their settlement sites earlier if their growth rates were higher than those of $C$. undulatus, but, in fact, the opposite was true. Mean growth of $C$. undulatus within their nursery habitats (BCMA) was nearly double that of $P$. areolatus or Epinephelus polyphekadion in coral rubble habitats. Other possible reasons for the shorter persistence time of groupers in their settlement microhabitats might include an earlier shift in diet, possibly the onset of piscivory, requiring the groupers to move to less complex substrates where their predation effectiveness (i.e. capture success) may be higher. Alternatively, the interstices among the coral rubble may be smaller than those of the BCMA habitat, forcing the groupers to seek alternative shelter at a smaller size.

The use of rubble habitat as nurseries, primarily in through-reef channels, is of great importance to management of Plectropomus areolatus and other species that may rely on coral rubble as a nursery habitat. Many channels are used as navigational routes in Palau and throughout the tropics. As such, dredging to maintain shipping depth can be a real threat, as the rubble areas on the sides of dredged channels can become buried with sediments, thereby degrading the quality of the habitat. In the course of selecting suit- able sites for this research, the author noted that many rubble areas in channels which were dredged had become choked with sediments, and no groupers were found in these areas.

There has been much research in recent years on the role of mangroves and seagrass beds as nursery habitats for coral reef fishes. These habitats have for many years been considered nurseries based on the relatively high abundance and putative survival of juvenile fishes. A large body of research in Bonaire and Curaçao (Nagelkerken et al. 2000a,b, 2001, 2002, Cocheret de la Morinière et al. 2002, Nagelkerken \& van der Velde 2002, Dorenbosch et al. 2006), Belize (Mumby et al. 2004, Mumby 2006), the Bahamas (Chittaro et al. 2005), and the Florida Keys (Mullin 1995) suggests that mangroves and seagrass beds are important nurseries for some species of reef fish. Research in Australia (Laegdsgaard \& Johnson 1995), southeast Florida (Thayer et al. 1987), New Caledonia (Thollot 1992), and Palau (present study) suggests that mangroves and seagrasses are less important than other coastal habitats in terms of nursery value for certain species. However, this discrepancy among locations in nursery value, particularly of mangroves, may simply be an artifact of the types of mangrove ecosystems studied. Areas in which mangroves were found to be important as reef fish nurseries (Bahamas, Florida Keys, Bonaire, and Curaçao) are dominated by fringing mangroves, in which salinity was high, turbidity was low, and the physicochemical environment was fairly similar to what fish might encounter on a coral reef (Cocheret de la Morinière et al. 2004). In contrast, areas in which mangroves were not important reef fish nurseries (Australia, Southeast Florida, New Caledonia, and Palau) are dominated by estuarine mangrove systems in which the salinity is low and/or variable, turbidity is very high, and the physicochemical environment very different to that of nearby coral reefs. Alternatively, the discrepancy between locations in use of mangroves may result from sampling difficulties in estuarine mangroves, including visual surveys hampered by poor visibility, problems with deploying nets or other gear among mangrove prop roots, or the presence of dangerous animals (crocodiles, alligators, bull sharks, etc.).

In addition to the variation in settlement among habitats, there was also a clear difference in settlement among sites. Cheilinus undulatus settled in higher densities to the same habitat types on the western coast of Palau compared to the eastern coast. The spawning areas of $C$. undulatus in Palau are not well known, although spawning sites have been identified along the western barrier reef (P. Colin, Coral Reef Research Foundation, unpubl. data). In contrast, the 2 grouper species settled in higher density along the eastern coast, despite the 2 major known spawning aggregations for these species being located at Ulong 
Channel and Ebiil Channel, on the western barrier reef. However, other aggregations may exist in areas not sampled in this study. Adult grouper and C. undulatus tend to be more common along the western reefs and in the Rock Islands (Fig. 1) than along the eastern reefs (Y. Golbuu, Palau International Coral Reef Center, unpubl. data). It is possible that this difference in settlement distribution between the grouper species and the $C$. undulatus arises from differences in the timing and location of spawning. More information is needed on tidal and current patterns around Palau and within Palau's lagoonal system before any speculation can be made as to why the spatial distribution of grouper spawning and settlement is so different.

In conclusion, the identification and mapping of nursery areas or other essential fish habitat (e.g. spawning aggregation sites) are critical to prioritizing habitats for conservation and restoration efforts, and indeed for any form of spatial management. To date, few marine protected areas have included specific essential fish habitat within boundaries, with the notable exception of spawning aggregation sites, which are generally small areas and easily defined. This is the case in Palau, where 2 major grouper spawning aggregation sites are protected year-round from fishing or other extractive activities. However, the formation of a new Protected Areas Network in Palau has yet to include other essential fish habitats, primarily because information on such habitats did not exist. The results of this study demonstrate that nursery habitats do exist for some commercially and culturally important reef fishes in Palau, and that some of these nurseries (e.g. rubble areas along the slopes of tidal channels) could be easily impacted by shipping or dredging activities, with potentially serious consequences for the adult fish populations. In addition, coastal development around the main island of Babeldoab has caused increases in sedimentation that could potentially choke essential nursery habitats with silt, degrading their quality to the point that they are no longer useful as nurseries. Future land-use planning and spatial management efforts in Palau and elsewhere in the tropics should account for nursery areas in addition to spawning sites. For this to be realized, much more research into habitat utilization patterns of commercially important reef fish is needed.

Acknowledgements. I thank the staff of the Palau International Coral Reef Center, particularly M. Udui, A. Bukurrou, and J. Kloulechad for their expert help in the field, and Y. Golbuu for helpful discussions of fish distribution. D. Burdick provided valuable assistance with habitat classification and mapping. This manuscript benefited greatly from critical reviews by T. Hourigan and 3 anonymous reviewers. Funding for this study was provided by grants from the National Oceanic and Atmospheric Administration (NOAA) Sea Grant
Fisheries Habitat Program and from the NOAA Coral Reef Conservation Program to the University of Guam Marine Laboratory. This paper is Contribution No. 1798 of The WorldFish Center and Contribution No. 590 of the University of Guam Marine Laboratory.

\section{LITERATURE CITED}

Beck MW, Heck KL, Able KW, Childers DL and 9 others (2001) The identification, conservation, and management of estuarine and marine nurseries for fish and invertebrates. BioScience 51:633-641

Benaka L (ed) (1999) Fish habitat: essential fish habitat and rehabilitation. American Fisheries Society, Bethesda, MD

Chittaro PM, Usseglio P, Sale PF (2005) Variation in fish density, assemblage composition and relative rates of predation among mangrove, seagrass and coral reef habitats. Environ Biol Fish 72:175-187

Cocheret de la Morinière E, Pollux BJA, Nagelkerken I, van der Velde G (2002) Post-settlement life cycle migration patterns and habitat preference of coral reef fish that use seagrass and mangrove habitats as nurseries. Estuar Coast Shelf Sci 55:309-321

Cocheret de la Morinière E, Nagelkerken I, van der Meij H, van der Velde G (2004) What attracts juvenile coral reef fish to mangroves: Habitat complexity or shade? Mar Ecol Prog Ser 144:139-145

Cook RR, Auster PJ (2005) Use of simulated annealing for identifying essential fish habitat in a multispecies context. Conserv Biol 19:865-875

Donaldson TJ, Sadovy Y (2001) Threatened fishes of the world: Cheilinus undulatus Ruppell, 1835 (Labridae). Environ Biol Fish 62:428

Dorenbosch M, Grol MGG, Nagelkerken I, van der Velde G (2006) Seagrass beds and mangroves as potential nurseries for the threatened Indo-Pacific humphead wrasse, Cheilinus undulatus and Caribbean humphead wrasse, Scarus guacamaia. Biol Conserv 129:277-282

Eagle JV, Jones GP, McCormick MI (2001) A multi-scale study of the relationships between habitat use and the distribution and abundance patterns of three coral reef angelfishes (Pomacanthidae). Mar Ecol Prog Ser 214: 253-265

Eggleston DB (1995) Recruitment in the Nassau grouper Epinephelus striatus: post-settlement abundance, microhabitat features, and ontogenetic habitat shifts. Mar Ecol Prog Ser 124:9-22

Johannes RE (1981) Words of the lagoon. University of California Press, Berkeley, CA

Johannes RE, Squire L, Graham T, Sadovy Y, Renguul H (1999) Spawning aggregations of groupers (Serranidae) in Palau. Marine Conservation Research Series No. 1, The Nature Conservancy

Koenig CC, Coleman FC (1998) Absolute abundance and survival of juvenile gags in sea grass beds in the northeastern Gulf of Mexico. Trans Am Fish Soc 127:44-55

Laegdsgaard P, Johnson CR (1995) Mangrove habitats as nurseries: unique assemblages of juvenile fish in subtropical mangroves in eastern Australia. Mar Ecol Prog Ser 126:67-81

Levin PS, Stunz GW (2005) Habitat triage for exploited fishes: Can we identify 'Essential Fish Habitat'? Estuar Coast Shelf Sci 64:70-78

Light PR, Jones GP (1997) Habitat preference in newly settled coral trout (Plectropomus leopardus: Serranidae). Coral Reefs 16:117-126 
Mullin SJ (1995) Estuarine fish populations among red mangrove prop roots of small overwash islands. Wetlands 15:324-329

Mumby P (2006) Connectivity of reef fish between mangroves and coral reefs: algorithms for the design of marine reserves at seascape scales. Biol Conserv 128:215-222

Mumby P, Edwards AJ, Arias-Gonzalez JE, Lindeman KC and 8 others (2004) Mangroves enhance the biomass of coral reef communities in the Caribbean. Nature 427:533-536

Myers RF (1999) Micronesian reef fishes, 3rd edn. Coral Graphics, Guam

Nagelkerken I, van der Velde G (2002) Non-estuarine mangroves harbor higher densities of juvenile fish than adjacent shallow-water and coral reef habitats in Curaçao (Netherlands Antilles). Mar Ecol Prog Ser 245:191-204

Nagelkerken I, Dorenbosch M, Verberk WCEP, Cocheret de la Morinière E, van der Velde G (2000a) Importance of shallow-water biotopes of a Caribbean bay for juvenile coral reef fishes: patterns in biotope association, community structure and spatial distribution. Mar Ecol Prog Ser 202:175-192

Nagelkerken I, van der Velde G, Gorisse MW, Meijer GJ, van't Hof $T$, den Hartog C (2000b) Importance of mangroves, seagrass beds and the shallow coral reef as a nursery for important coral reef fishes, using a visual census technique. Estuar Coast Shelf Sci 51:31-44

Nagelkerken I, Kleijnen S, Klop T, van den Brand RACJ, Cocheret de la Morinière E, van der Velde G (2001) Dependence of Caribbean coral reef fishes on mangroves and seagrass beds as nursery habitats: a comparison of fish faunas between bays with and without mangroves/ seagrass beds. Mar Ecol Prog Ser 214:225-235

Nagelkerken I, Roberts CM, van der Velde G, Dorenbosch M, van Riel MC, Cocheret de la Morinière E, Nienhaus PH (2002) How important are mangroves and seagrass beds for coral reef fish? The nursery hypothesis tested on an island scale. Mar Ecol Prog Ser 244:299-305

Editorial responsibility: Charles Birkeland (Contributing Editor), Honululu, Hawaii, USA
Rhodes KL, Sadovy Y (2002) Temporal and spatial trends in spawning aggregations of camouflage grouper, Epinephelus polyphekadion, in Pohnpei, Micronesia. Environ Biol Fish 63:27-39

Rudd MA, Tupper MH (2002) The impact of Nassau grouper size and abundance on scuba diver site selection and MPA economics. Coast Manage 30:133-151

Sadovy Y, Kulbicki M, Labrosse P, Letourneur Y, Lokani P, Donaldson TJ (2003a) The humphead wrasse, Cheilinus undulatus: synopsis of a threatened and poorly known giant coral reef fish. Rev Fish Biol Fish 13:327-364

Sadovy YJ, Donaldson TJ, Graham TR, McGilvray F and 5 others (2003b) The live reef food fish trade: while stocks last. Asian Development Bank, Manila

Sullivan KM, Sluka R (1996) The ecology of shallow-water groupers (Pisces: Serranidae) in the Upper Florida Keys, USA. In: Arrequin-Sanchez F, Munro JL, Baigos MC, Pauly D (eds) Biology, fisheries and culture of tropical groupers and snappers. ICLARM Conf Proc 48:74-84

Thayer GW, Colby DR, Hettler WF Jr (1987) Utilization of the red mangrove prop root habitat by fishes in south Florida. Mar Ecol Prog Ser 35:25-38

Thollot P (1992) Importance of mangroves for Pacific reef fish species: Myth or reality? In: Richmond RH (ed) Proc 7th Int Coral Reef Symp, Vol 2. University of Guam, Mangilao, p 934-941

Tupper M, Boutilier RG (1995) Effects of habitat on settlement, growth and post-settlement survival of Atlantic cod (Gadus morhua). Can J Fish Aquat Sci 52:1834-1841

Tupper M, Boutilier RG (1997) Effects of habitat on settlement, growth, predation risk and post-settlement mortality of a temperate reef fish. Mar Ecol Prog Ser 151: 225-236

Tupper M, Juanes F (1999) Effects of a marine reserve on production dynamics of grunts (Pisces: Haemulidae) in Barbados. Environ Biol Fish 55:53-63

Submitted: January 12, 2006; Accepted: July 6, 2006

Proofs received from author(s): February 13, 2007 